\title{
Conversion from forests to pastures in the Colombian Amazon leads to differences in dead wood dynamics depending on land management practices
}

Diego Navarrete a,*, Stephen Sitch a, Luiz E.O.C. Aragão a,b, Lucio Pedroni c ${ }^{\text {c }}$, Alvaro Duque d,

a) Department of Geography, College of Life and Environmental Sciences, University of Exeter, Rennes Drive, Exeter EX4 4RJ, UK.

b) Remote Sensing Division, National Institute for Space Research, Av. dos Astronautas, 1758, 12227-010, São José dos Campos, São Paulo, Brazil.

c) Carbon Decisions International, Residencial la Castilla, de la primera entrada 6ta casa a mano derecha, Paraíso de Cartago, Costa Rica.

d) Departamento de Ciencias Forestales, Universidad Nacional de Colombia - Sede Medellín, Medellín, Colombia.

*Corresponding author: Diego Navarrete, Department of Geography, College of Life and Environmental Sciences, University of Exeter, Rennes Drive, Exeter EX4 4RJ, UK; email: danavarretee@gmail.com; phone: +44 (0) 1392723331

Key words: Colombian Amazon; coarse woody debris; dead wood carbon pool; forest-topasture conversion; grazing intensity; REDD+.

Article type: Research article 


\section{Abstract}

Dead wood, composed of coarse standing and fallen woody debris (CWD), is an important carbon (C) pool in tropical forests and its accounting is needed to reduce uncertainties within the strategies to mitigate climate change by reducing deforestation and forest degradation (REDD+). To date, information on CWD stocks in tropical forests is scarce and effects of land-cover conversion and land management practices on CWD dynamics remain largely unexplored. Here we present estimates on CWD stocks in primary forests in the Colombian Amazon and their dynamics along 20 years of forest-to-pasture conversion in two sub-regions with different management practices during pasture establishment: high-grazing intensity (HG) and low-grazing intensity (LG) sub-regions. Two 20-year-old chronosequences describing the forest-to-pasture conversion were identified in both sub-regions. The lineintersect and the plot-based methods were used to estimate fallen and standing CWD stocks, respectively. Total necromass in primary forests was similar between both sub-regions (35.6 $\pm 5.8 \mathrm{Mg} \mathrm{ha}^{-1}$ in $\mathrm{HG}$ and $37.0 \pm 7.4 \mathrm{Mg} \mathrm{ha}^{-1}$ in LG). An increase of $\sim 124 \%$ in CWD stocks followed by a reduction to values close to those at the intact forests were registered after slash-and-burn practice was implemented in both sub-regions during the first two years of forest-to-pasture conversion. Implementation of machinery after using fire in HG pastures led to a reduction of $82 \%$ in CWD stocks during the second and fifth years of pasture establishment, compared to a decrease of $41 \%$ during the same period in LG where mechanization is not implemented. Finally, average necromass 20 years after forest-to-pasture conversion decreased to $3.5 \pm 1.4 \mathrm{Mg} \mathrm{ha}^{-1}$ in $\mathrm{HG}$ and $9.3 \pm 3.5 \mathrm{Mg} \mathrm{ha}^{-1}$ in $\mathrm{LG}$, representing a total reduction of between $90 \%$ and $75 \%$ in each sub-region, respectively. These results highlight the importance of low-grazing intensity management practices during ranching activities in the Colombian Amazon to reduce $\mathrm{C}$ emissions associated with land-cover change from forest to pasture. 


\section{Introduction}

Deforestation in the tropics generates $7-14 \%$ of the total carbon dioxide $\left(\mathrm{CO}_{2}\right)$ emissions globally (Harris et al., 2012) becoming the second most important source of greenhouse gases (GHG) after fossil fuel combustion (Don et al., 2011). Conversion from forest to pasture is the most common land-cover change in the Amazon basin (Fearnside and Barbosa, 1998; Asner et al., 2004; Desjardins et al., 2004), although the area dedicated to agriculture activities, particularly soybean crops, has increased since the 2000s (Nepstad et al., 2008; Pacheco et al., 2012). After cutting the forest, management practices to establish pasture in Amazonia may include: the use of fire to eliminate the maximum amount of plant material left by deforestation or to control the expansion of secondary vegetation (Fearnside et al., 1993; Kauffman et al., 1995; Kauffman et al., 1998; IPCC, 2006; Aragão and Shimabukuro, 2010), implemented once or more times depending on burning efficiency of dead wood (Fearnside et al., 1999; Fearnside et al., 2001); the use of machinery to remove unburned woody debris (Murty et al., 2002; Marin-Spiotta et al., 2009); the introduction of improved pastures and legume species (Alarcón and Tabares, 2007; Mosquera et al., 2012), or the use of fertilizers and lime to improve pasture productivity (Jiménez and Lal, 2006; Fisher et al., 2007). Management practices implemented during pasture establishment are as important as landcover changes in determining carbon (C) dynamics and GHG emissions/removals (Fearnside and Barbosa, 1998; Dias-Filho et al., 2000; Berenguer et al., 2014; Luyssaert et al., 2014), and among them, grazing intensity can significantly contribute to increase or reduce $\mathrm{C}$ stocks (Uhl et al., 1988).

Coarse dead wood, also called coarse woody debris (CWD), is one of the C pools defined by the Intergovernmental Panel Climate Change (IPCC) to report on C stocks changes and 
GHG emissions/removals associated with land-use changes within the Agriculture, Forestry and Other Land Use (AFOLU) sector (IPCC, 2006). CWD includes standing and fallen dead trees and all dead wood pieces with diameter $\geq 10 \mathrm{~cm}$ that together store on average $\sim 30 \%$ of the total C stored in the aboveground C pools in tropical forests (Harmon et al., 1995; Clark et al., 2002; Creed et al., 2004; Rice et al., 2004; Baker et al., 2007; Palace et al., 2007). CWD is also an important component in many ecological processes in the forest as it provides a habitat for some micro- and macro-organisms (Gibss et al., 1993; Eggleton et al., 1995; Grove, 2002; Pedlar et al., 2002), participates in nutrient cycling and influences the energy flux within the ecosystem (Harmon et al., 1986; Chao et al., 2008).

Due to its importance within the tropical forests, C emissions from CWD potentially contribute a considerable amount of total $\mathrm{CO}_{2}$ emissions associated with deforestation (Palace et al., 2008). However, information on CWD stocks and variation with land-cover and landuse changes is scarce (Baker et al., 2007; Palace et al., 2012). Recently, two studies were published on the impact of forest degradation on dead wood $\mathrm{C}$ pool in primary forests in eastern Brazilian Amazon (Berenguer et al., 2014) and Malaysia (Pfeifer et al., 2015) with the potential to improve GHG emissions accountability. However, there are no studies assessing the impact of the land-cover change from forest to pasture on CWD stocks and C dynamics.

Strategies to mitigate $\mathrm{CO}_{2}$ emissions associated with deforestation such as $\mathrm{REDD}+$ require reporting of emission factors, defined as the emissions/removals of all important GHG associated with land-cover conversion in all relevant $\mathrm{C}$ pools (i.e. total changes in $\mathrm{C}$ stocks), and activity data, referring to the size of a deforested or degraded area (Verchot et al., 2012). Both emission factors and activity data should be included within the forest reference emission levels (FREL) that countries willing to access result-based payments through 
REDD+ activities must submit to the UNFCCC, as benchmarks for assessing country's performance (FAO, 2014). Due to lack of information, dead wood C pool was not included in any of the FRELs recently submitted to the UNFCCC by Brazil, Colombia, Ecuador, Guyana, Malaysia and Mexico (Conafor, 2014; GFC, 2014; MADS, 2014; MAE, 2014; MMA, 2014; MNRE, 2014). Colombia, in particular, included the above- and below-ground biomass $\mathrm{C}$ pools in forests within its FREL, but neither the dead wood $\mathrm{C}$ pool nor their change after conversion from forest to any post-deforestation land-use category were included (MADS, 2014). Nonetheless, under the UNFCCC Stepwise Approach (UNFCCC, 2012), countries have the option to improve their initial FRELs by incorporating high-quality data, improved methodologies and additional $\mathrm{C}$ pools developed from country- or region-specific information and field measurements following an IPCC Tier 3 approach.

Here we present new Tier 3 information and emission factors on dead wood $\mathrm{C}$ pool and its dynamics during 20 years of forest-to- pasture conversion under different management practices in the Colombian Amazon. In this study we addressed the following general question: to what extent land-cover change from forest to pasture and subsequent land management practices affect dead wood C pool in the Colombian Amazon? Therefore, we aimed to better quantify CWD stocks and changes with forest-to-pasture conversion in the Colombian Amazon in support of REDD+ initiatives. Specifically, our objectives were to:

1. Quantify the volume, wood density and necromass of CWD in primary forests of the Colombian Amazon.

2. Quantify the changes in CWD stocks in two sub-regions of the Colombian Amazon and describe the influence of the high- and low-grazing intensity management practices after 20 years of forest-to-pasture conversion on the dead wood dynamics. 
3. Determine the emission factors of dead wood $\mathrm{C}$ pool in both sub-regions according to IPCC (2006), by applying region-specific equations developed in this study describing the CWD dynamics along 20 years of forest-to-pasture conversion.

\section{Materials and methods}

\subsection{Site description}

The study was carried out in two sub-regions of the Colombian Amazon where management practices after forest-to-pasture conversion differ in terms of grazing intensity. According to Maecha et al. (2002), the carrying capacity of pastures in the Colombian Amazon is $0.8-1.0$ heads of forage-fed livestock per hectare (HFFL). Therefore, for this study we defined the high- and low-grazing intensity areas (hereafter HG and LG, respectively) as those pastures in which the number of HFFL per hectare is above and below 1.0 head of livestock ha ${ }^{-1}$, respectively (Fig. 1). High-grazing intensity management practices are evident in most of the pasture areas located in $\mathrm{HG}$, where pastures cover $\sim 662000$ ha (3.6\%) from a total area of 18237519 ha (Ideam, 2014) and cattle density by 2013 was 1777549 heads of forage-fed livestock (HFFL), averaging 2.7 HFFL ha ${ }^{-1}$, according to the National Livestock Inventory of Colombia (Fedegan, 2013). By contrast, pastures in LG in 2013 covered $\sim 45000$ ha $(0.2 \%)$ from a total area of 23387251 ha (Ideam, 2014), and cattle density by the same year was 5328 HFFL (Fedegan, 2013), averaging 0.1 HFFL ha-1. HG and LG also coincide with the division of the Colombian Amazon made by government, as high- and lowdeforestation risk sub-regions, respectively (Gonzáles et al., 2014). Pastures are the predominant post-deforestation land cover across the whole Colombian Amazon and are mostly located in HG (Cabrera et al., 2011). According to Bowman et al. (2012), up to 80\% of the pasture area in the Colombian Amazon is occupied by farms implementing the 
extensive cattle ranching system. However, whereas in HG farmers tend to manage their pastures by planting Brachiaria humidicola or B. decumbens, or by mixing these species with legume species such as Arachis pintoi or Desmodium ovalifolium (Alarcón \& Tabares, 2007; Mosquera et al., 2012), in LG it is common to find pasture areas where grasses (C4 vegetation) are mixed with shrubs and trees (C3 vegetation). The use of fire is a commonlyused management practice in both sub-regions to eliminate the remnant dead wood and other non-readily-decomposable material left after deforestation. However, whilst in HG the implementation of machinery to remove most of the residual dead wood not consumed completely by fire and to eliminate the secondary vegetation growing in the pasture matrix is a frequent practice, the use of machinery in LG is reduced or absent due to the limitation to transport heavy equipment to remote areas within the forest of this sub-region.

HG is located in the west of the Colombian Amazon where the major land forms are lowgradient foot slopes and dissected plains, extending eastward between 800-200 m above sea level, and the predominant soils are Haplic Ferralsols and Haplic Acrisols, respectively. However, Ferralsols occur only in a relatively small portion of the western side of $\mathrm{HG}$, in the transition of the Andean and Amazon regions of Colombia. Mosquera et al. (2012) found no significant differences in total soil organic carbon and the content of other elements in pastures of the same age located in Ferralsols and Acrisols sites within HG. LG is located in the east of the Colombian Amazon where the land forms are dominated by dissected plains between 90-80 m above sea level, and the soils are mainly Haplic Acrisols (van Engelend \& Dijkshoorn, 2013). For this study mean annual precipitation and temperature were calculated as the average between 1970 and 2013 in HG, and between 1972 and 2012 in LG. Mean annual precipitation and mean annual temperature in $\mathrm{HG}$ are $3723.9 \pm 408.6 \mathrm{~mm}$ and $26.6 \pm 0.6$ ${ }^{\circ} \mathrm{C}$, respectively, and in $\mathrm{LG}$ are $3351.1 \pm 341.7 \mathrm{~mm}$ and $25.9 \pm 0.4{ }^{\circ} \mathrm{C}$, respectively. On average 
evapotranspiration never exceeds precipitation in either sub-regions. The Tropical Moist Forest is the dominant forest type in the Colombian Amazon, covering a total area of $\sim 39$ million hectares and storing $136.6 \pm 4.9 \mathrm{Mg} \mathrm{C} \mathrm{ha}^{-1}$ and $27.5 \pm 0.9 \mathrm{Mg} \mathrm{C}^{-1}$ in the above- and below-ground biomass, respectively (Phillips et al., 2014). 


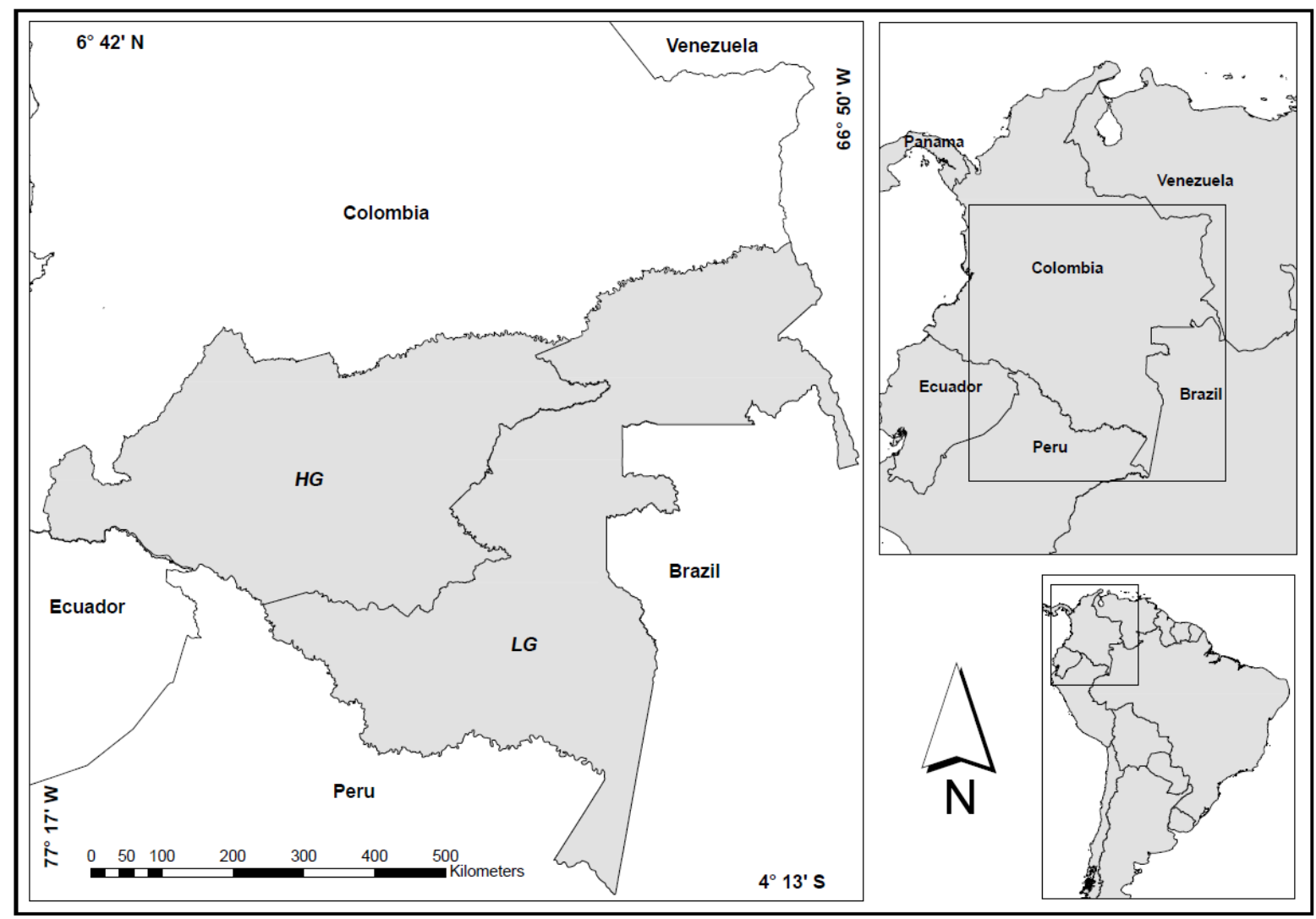

Fig. 1. Location of the high- and low-grazing intensity sub-regions in the Colombian Amazon (HG and LG, respectively). Panels on the right side show the location of Colombia within South America. 


\subsection{Chronosequence approach}

One chronosequence of six sites representing the forest-to-pasture conversion was identified in each of the two sub-regions of the Colombian Amazon, through the use of satellite images, official maps of deforestation in Colombia, and interviews with landowners and local people, who also provided information about the land-use history and management. Both chronosequences covered a period of 20 years of forest-to-pasture conversion, with the primary forest as the starting point (i.e. 0 years since deforestation). The chronosequences were established in areas of pasture that previously had a forest cover and have been kept as pasture ever since the deforestation event. In order to have a more representative sequence of the forest-to-pasture conversion, the chronosequences included the first stages of the pasture establishment, corresponding to areas recently deforested (i.e. around one year since deforestation) and areas recently burned to clean the biomass remaining from deforestation (i.e. one to two years after deforestation). The rest of the chronosequence was established in pastures of around 5, 12 and 20 years old since deforestation in both sub-regions (Table 1).

The landscape of the area devoted to cattle ranching in HG is mainly dominated by extensive pastures established during the last decades, with the sporadic occurrence of small $(<1.0 \mathrm{ha})$, scattered patches of remnant forest. The distance from the selected pasture areas to the closest forest in $\mathrm{HG}$ was $<1.0 \mathrm{~km}$ in the case of the 1- and 2-year-old pastures, $\sim 4.0 \mathrm{~km}$ in the case of the 5-year-old pasture and $>30 \mathrm{~km}$ in the case of the 12- and 20-year-old pastures. In contrast, the areas dedicated to cattle ranching in LG are embedded within the primary forest matrix, so selected pasture areas from all stages of the chronosequence in this subregion are surrounded by the adjacent forest. 
Table 1 Location and time after deforestation of the identified sites comprising both chronosequences in the high-grazing intensity (HG) and the low-grazing intensity (LG) subregions in the Colombian Amazon.

\begin{tabular}{|c|c|c|}
\hline Site & $\begin{array}{l}\text { Post- } \\
\text { deforestation } \\
\text { time (years) }\end{array}$ & Location (Lat., Long.) \\
\hline \multicolumn{3}{|l|}{$H G$} \\
\hline Primary forest & 0.0 & $01^{\circ} 39^{\prime} 41.8^{\prime \prime} \mathrm{N}, 75^{\circ} 37^{\prime} 41.8^{\prime \prime} \mathrm{W}$ \\
\hline 1-yr-old pasture & 0.6 & $01^{\circ} 39^{\prime} 53.8^{\prime \prime} \mathrm{N}, 75^{\circ} 37^{\prime} 30.0^{\prime \prime} \mathrm{W}$ \\
\hline 2-yr-old pasture & 1.7 & $01^{\circ} 39^{\prime} 38.7^{\prime \prime} \mathrm{N}, 75^{\circ} 37^{\prime} 28.1^{\prime \prime} \mathrm{W}$ \\
\hline 5-yr-old pasture & 5.4 & $01^{\circ} 44^{\prime} 02.8^{\prime \prime} \mathrm{N}, 75^{\circ} 38^{\prime} 03.1^{\prime \prime} \mathrm{W}$ \\
\hline 12-yr-old pasture & 12.0 & $01^{\circ} 27^{\prime} 30.4^{\prime \prime} \mathrm{N}, 75^{\circ} 37^{\prime} 34.8^{\prime \prime} \mathrm{W}$ \\
\hline 20-yr-old pasture & 20.0 & $01^{\circ} 27^{\prime} 22.5^{\prime \prime} \mathrm{N}, 75^{\circ} 37^{\prime} 57.9^{\prime \prime} \mathrm{W}$ \\
\hline \multicolumn{3}{|l|}{$L G$} \\
\hline Primary forest & 0.0 & $04^{\circ} 10^{\prime} 10.1^{\prime \prime} \mathrm{S}, 69^{\circ} 55^{\prime} 17.0^{\prime \prime} \mathrm{W}$ \\
\hline 1-yr-old pasture & 0.7 & $04^{\circ} 09^{\prime} 53.6^{\prime \prime} \mathrm{S}, 69^{\circ} 54^{\prime} 50.0^{\prime \prime} \mathrm{W}$ \\
\hline 2-yr-old pasture & 1.5 & $04^{\circ} 09^{\prime} 49.3^{\prime \prime} \mathrm{S}, 69^{\circ} 55^{\prime} 02.8^{\prime \prime} \mathrm{W}$ \\
\hline 5-yr-old pasture & 5.0 & $04^{\circ} 09^{\prime} 51.5^{\prime \prime} \mathrm{S}, 69^{\circ} 54^{\prime} 41.2^{\prime \prime} \mathrm{W}$ \\
\hline 12-yr-old pasture & 12.0 & $04^{\circ} 09^{\prime} 58.8^{\prime} \mathrm{S}, 69^{\circ} 54^{\prime} 10.5^{\prime \prime} \mathrm{W}$ \\
\hline 20-yr-old pasture & 20.0 & $04^{\circ} 10^{\prime} 02.2^{\prime \prime} \mathrm{S}, 69^{\circ} 55^{\prime} 17.9^{\prime \prime} \mathrm{W}$ \\
\hline
\end{tabular}




\subsection{Necromass estimate}

Mean necromass $N\left(\mathrm{Mg} \mathrm{ha}^{-1}\right)$ of standing and fallen CWD at each stage $s t$ of both chronosequences was calculated as the product of the volume and wood density of the CWD pieces, as:

$N_{s t}=V_{s t} \times \rho_{s t}$

and the standard error of $N_{i}$ was calculated following Taylor (1997), as:

$S E_{N s t}=S E_{\rho s t} V_{s t}+S E_{V s t} \rho_{s t}$

where $S E_{\rho s t}$ and $S E_{V s t}$ represent the standard error of wood density and volume, respectively. Corrected necromass of standing and fallen CWD was obtained by multiplying $N_{s t}$ by the void space proportion of CWD at every stage of each chronosequence, and total necromass for a specific stage was obtained as the sum of the corrected standing and fallen CWD necromass in the same stage. Propagated standard error for total necromass was calculated as the square root of the sum of the squared standard error of the corrected standing and fallen CWD necromass. A detailed description of the procedure and equations implemented to estimate standing and fallen CWD volume, CWD density and the void space proportion of CWD is presented in the Supplementary Information accompanying this study, and is based in the protocol proposed by Yepes et al. (2011) to measure dead wood in the field.

\subsection{Statistical analysis}


All data were tested for normality and homogeneity of variance. The Rayleigh's test for circular uniformity was performed to verify that the orientation of fallen CWD was randomly distributed (Zar, 1999). In order to establish possible differences in mean wood density, volume and necromass of standing and fallen CWD between similar stages of the forest-topasture conversion between $\mathrm{HG}$ and LG, and among the six stages of each chronosequence, $t$ tests of independent samples and analyses of variance (ANOVA), respectively, were performed. When significant differences were found, post hoc Tukey-HSD tests were made. The model to predict CWD wood density was developed using the package Lattice version 0.20-29 of the software $\mathrm{R}$ ( $\mathrm{R}$ version 3.1.1). In order to obtain the pattern of variation of dead wood during the forest-to-pasture conversion under the specific management practices implemented in each sub-region, linear, exponential and logarithmic regression analyses were tested and the model which best fitted the data in every case was selected. The selected equations were used to establish the emission factors for the total change in dead wood C pool due to the forest-to-pasture conversion after 20 years of deforestation in both sub-regions of the Colombian Amazon, according to the IPCC (2006) Tier 3 approach. Thus, the results of CWD necromass expressed in $\mathrm{Mg} \mathrm{ha}^{-1}$ were converted to $\mathrm{Mg} \mathrm{C} \mathrm{ha}^{-1}$ by using a factor of 0.5 assuming that $\mathrm{C}$ corresponds to $50 \%$ of total necromass (Feldpausch, et al., 2004; IPCC, 2006), and then converted to tonnes of $\mathrm{CO}_{2}$ equivalent per hectare $\left(\mathrm{t}^{\mathrm{CO}_{2}} \mathrm{e} \mathrm{ha}^{-1}\right)$ by using the C-to- $\mathrm{CO}_{2} \mathrm{e}$ conversion factor of 44/12 (UNFCCC, 2012). All the analyses were evaluated with a significance level of $P<0.05$.

\section{Results}

\subsection{Void space and wood density}


Mean void space proportion in CWD was extremely low in both sub-regions, ranging from $2.2 \%$ and $3.9 \%$ in the forests to $0.0 \%$ and $0.3 \%$ in the 20 -year-old pastures in $\mathrm{HG}$ and LG, respectively (Table S1). There were no significant differences in mean void space proportion either between similar stages of each chronosequence in HG and LG, or across different stages within the same sub-region. The best model to predict wood density of standing and fallen CWD based on penetration data using the dynamic penetrometer and calibrated with laboratory measurements of wood density $\left(r^{2}=0.65 ; P<0.0001 ; \mathrm{df}=135\right.$; $\mathrm{AIC}=-175.7$; Fig. 2), is expressed as:

$\rho_{i}=0.68574-0.46883\left(\log _{10} P_{i}+1\right)+0.33388 I+0.36301\left(\log _{10} P_{i}+1\right) I$

where $\rho_{i}\left(\mathrm{~g} \mathrm{~cm}^{-3}\right)$ is the wood density of the CWD piece $i$ and $P_{i}(\mathrm{~cm})$ is the penetration of the penetrometer into the wood of the CWD piece $i(I=0$, if $P \leq 1 ; I=1$, if $P>1)$. 


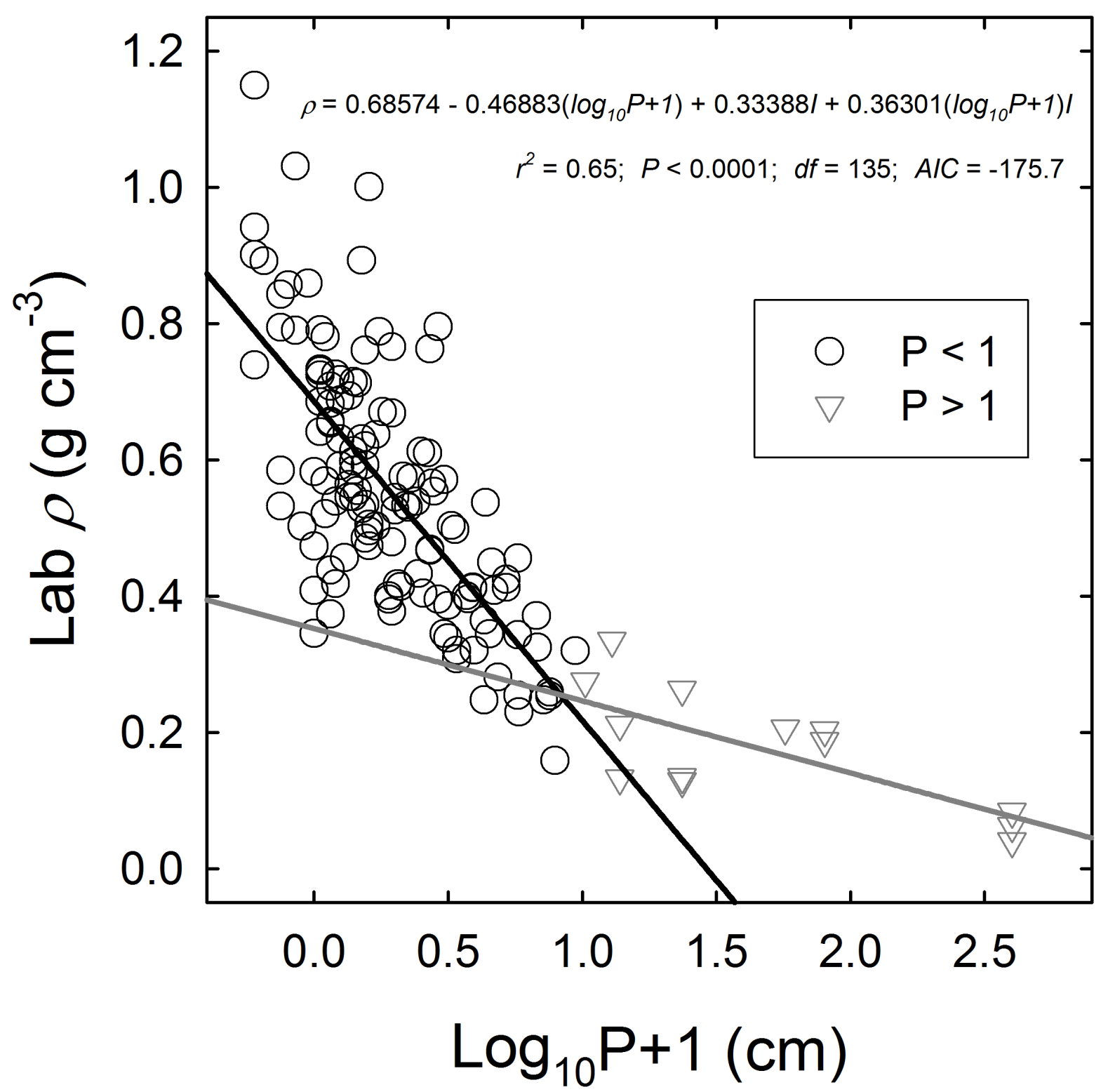

Fig. 2. Relationship between penetration (P) into the wood of the CWD using a dynamic penetrometer and wood density measured at the laboratory $(\operatorname{Lab} \rho) . r^{2}=0.65 ; P<0.0001$; df $=135 ; \mathrm{AIC}=-175.7$ 
Mean wood density was significantly higher in LG in the forest and 2-year-old pasture in the case of standing CWD, and in the 1-, 2-, and 20-year-old pastures in the case of fallen CWD. Even though the rest of the comparisons between sub-regions were not significant, wood density of standing and fallen CWD were generally lower in HG compared to LG (Fig. 3; Table S2). Wood density of fallen CWD was significantly lower in the forests of both subregions, and increased with pasture age with no significant differences among them. On the other hand, although wood density of standing CWD was lower in forests in HG and LG, there were no significant differences in CWD wood density across most of the pasture stages in each sub-region (Fig. 3; Table S2).

\subsection{CWD volume and necromass}

There were no significant differences in the volume of standing and fallen CWD between similar stages of each chronosequence in HG and LG. Volume of standing CWD varied significantly among forest-to-pasture stages in $\mathrm{HG}$, ranging from $21.1 \pm 5.4$ and $24.7 \pm 4.6 \mathrm{~m}^{3}$ $\mathrm{ha}^{-1}$ in the forest and 1-year-old pasture stages to $2.3 \pm 1.0 \mathrm{~m}^{3} \mathrm{ha}^{-1}$ in the 20 -year-old pasture. No significant variation in the volume of standing CWD among stages was found in LG, although the highest values were registered during the first two stages of the chronosequence (Fig. 3; Table S3).

Significant differences were found in the volume of fallen CWD among stages of both chronosequences. Volume of fallen CWD in forests in HG was $56.0 \pm 3.6 \mathrm{~m}^{3} \mathrm{ha}^{-1}$. However, during the first stage of pasture establishment it increased $112 \%$ from its original value, after which there was a progressive reduction until a value of $3.8 \pm 0.1 \mathrm{~m}^{3} \mathrm{ha}^{-1}$ recorded in the 20year-old pasture. A similar pattern occurred in LG, where the volume of fallen CWD at 
forests was $66.8 \pm 5.6 \mathrm{~m}^{3} \mathrm{ha}^{-1}$ and increased $71 \%$ after deforestation. Unlike HG, the decrease in volume between the 2- and 5-year-old pastures was less pronounced in LG (i.e. from 52.9 \pm 3.4 to $9.1 \pm 0.1 \mathrm{~m}^{3} \mathrm{ha}^{-1}$ in $\mathrm{HG}$ vs. $40.7 \pm 1.6$ to $25.7 \pm 0.7 \mathrm{~m}^{3} \mathrm{ha}^{-1}$ in $\left.\mathrm{LG}\right)$, and the value registered in the 20-year-old pasture was $8.4 \pm 0.1 \mathrm{~m}^{3} \mathrm{ha}^{-1}$ (Fig. 3; Table S3).

Mean standing and fallen CWD necromass values slightly lower when corrected for void space proportion. Total (standing + fallen) CWD corrected necromass was similar between HG and LG during the first three stages of pasture establishment, where values increased $124 \%$ in $\mathrm{HG}$ and $123 \%$ in LG just after deforestation, and then decreased during the 2-yearold pastures to values slightly lower than those recorded at forests. However, while there was a sharp reduction of $82 \%$ in total CWD between the 2- and 5-year-old pastures and a small amount recorded in the 20-year-old pasture $\left(3.5 \pm 1.4 \mathrm{Mg} \mathrm{ha}^{-1}\right)$ in $\mathrm{HG}$, total CWD only was reduced by $41 \%$ between the 2 - and the 5 -year-old pastures and decreased to $9.3 \pm 3.5 \mathrm{Mg} \mathrm{ha}^{-1}$ at the last stage of the chronosequence in LG (Table 2). 

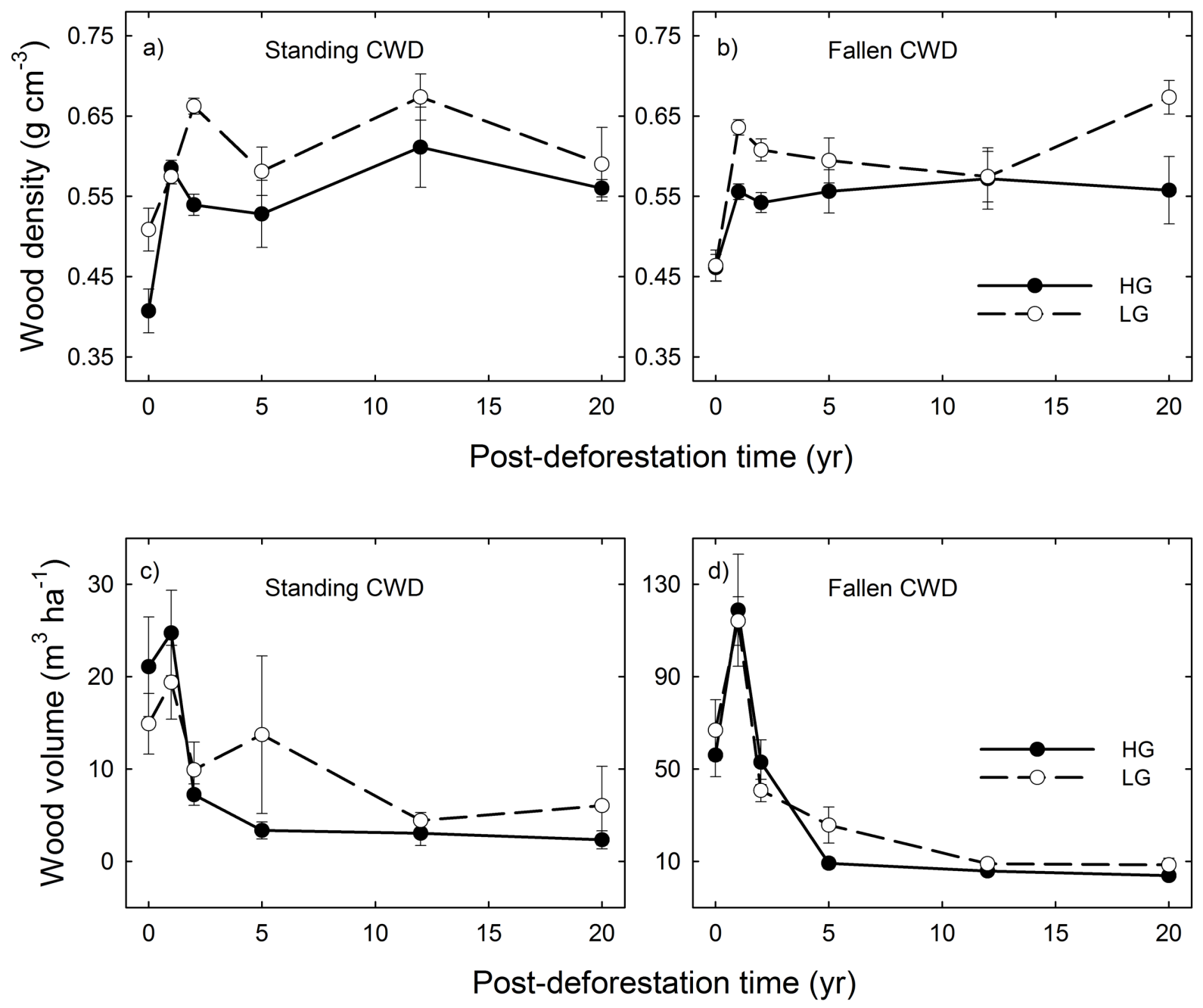

Fig. 3. Mean wood density (a and $b ; \mathrm{g} \mathrm{cm}^{-3}$ ) and volume ( $\mathrm{c}$ and $\mathrm{d} ; \mathrm{m}^{3} \mathrm{ha}^{-1}$ ) of standing and fallen CWD in the high-grazing intensity (HG) and the low-grazing intensity (LG) subregions of the Colombian Amazon. Bars represent the standard error of the mean ( $\mathrm{n}$ for wood density is presented in Table S2; $\mathrm{n}$ for volume is presented in Table S3) 
Table 2 Mean necromass ( \pm propagated SE, $\mathrm{Mg} \mathrm{ha}^{-1}$ ) corrected by void space proportion of standing and fallen CWD, and total mean necromass (standing + fallen) in the high-grazing intensity (HG) and the low-grazing intensity (LG) sub-regions of the Colombian Amazon. Lowercase letters indicate significant differences among stages of the same sub-region $(P<0.0001)$, and uppercase letters represent significant differences in uncorrected necromass of fallen CWD between similar stages from each sub-region $(P<0.0001)$.

\begin{tabular}{|c|c|c|c|c|c|c|c|c|c|c|c|c|c|}
\hline \multirow{3}{*}{$\begin{array}{l}\text { Forest-to-pasture } \\
\text { conversion in } \mathrm{HG}\end{array}$} & \multicolumn{6}{|c|}{ Necromass $\left(\mathrm{Mg} \mathrm{ha}^{-1}\right)$} & \multirow{3}{*}{$\begin{array}{l}\begin{array}{l}\text { Forest-to-pasture } \\
\text { conversion in LG }\end{array} \\
\text { Primary forest }\end{array}$} & \multicolumn{6}{|c|}{ Necromass $\left(\mathrm{Mg} \mathrm{ha}^{-1}\right)$} \\
\hline & \multicolumn{2}{|c|}{ Standing } & \multicolumn{2}{|c|}{ Fallen } & \multicolumn{2}{|l|}{ Total } & & \multicolumn{2}{|c|}{ Standing } & \multicolumn{2}{|c|}{ Fallen } & \multicolumn{2}{|c|}{ Total } \\
\hline & 9.6 & $(2.7)^{\mathrm{ab}}$ & 26.1 & $(5.2)^{\mathrm{b}}$ & 35.6 & $(5.8)$ & & 7.2 & $(2.0)$ & 29.8 & $(7.1)^{b}$ & 37.0 & (7.4) \\
\hline 1-yr pastures & 14.4 & $(2.9)^{\mathrm{a}}$ & 65.1 & $(14.6)^{\mathrm{a}}$ & 79.6 & (14.9) & 1-yr pastures & 11.5 & $(2.5)$ & 71.1 & $(7.8)^{\mathrm{a}}$ & 82.5 & (8.2) \\
\hline 2-yr pasture & 3.9 & $(0.7)^{\mathrm{bc}}$ & 28.7 & $(5.9)^{\mathrm{b}}$ & 32.7 & $(5.9)$ & 2-yr pasture & 6.3 & (2.1) & 25.3 & $(3.5)^{\mathrm{b}}$ & 31.6 & (4.1) \\
\hline 5-yr pasture & 1.4 & $(0.6)^{\mathrm{c}}$ & 4.9 & $(1.6)^{\mathrm{Ac}}$ & 6.3 & $(1.7)$ & 5-yr pasture & 7.4 & (5.3) & 14.5 & $(5.3)^{\mathrm{Abc}}$ & 22.0 & (7.5) \\
\hline 12-yr pasture & 1.9 & $(1.0)^{\mathrm{c}}$ & 3.4 & $(1.3)^{\mathrm{c}}$ & 5.3 & (1.6) & 12-yr pasture & 2.8 & $(0.7)$ & 5.3 & $(1.6)^{\mathrm{c}}$ & 8.0 & (1.8) \\
\hline 20-yr pasture & 1.3 & $(0.6)^{\mathrm{c}}$ & 2.2 & $(1.2)^{\mathrm{c}}$ & 3.5 & (1.4) & 20-yr pasture & 3.9 & (2.8) & 5.4 & $(2.1)^{\mathrm{c}}$ & 9.3 & (3.5) \\
\hline
\end{tabular}




\subsection{CWD necromass turnover and emission factors (IPCC Tier 3 approach)}

Total CWD significantly decrease along the 20 years of forest-to-pasture conversion in both sub-regions of the Colombian Amazon $\left(r^{2}=0.25, P<0.0001\right.$ in $\mathrm{HG}$ and $r^{2}=0.26, P<$ 0.0001 in LG; Fig. 4a), as a consequence of the significant reduction of fallen CWD $\left(r^{2}=\right.$ $0.38, P<0.0001$ in HG and $r^{2}=0.41, P<0.0001$ in LG; Fig. 4b) and standing CWD $\left(r^{2}=\right.$ $0.50, P<0.0001$ in $\mathrm{HG}$ and $r^{2}=0.13, P<0.0001$ in LG; Fig. 4c) during the same period. IPCC (2006) recommends developing emission factors of dead wood C pool changes for lands converted to grasslands, including the forest-to-pasture conversion, and the long term legacy effects of land-use management within a Tier 3 approach. Accordingly, the following equations and parameters were fitted to the data in order to describe the change in total CWD stocks with time since conversion in $\mathrm{HG}$ and LG, respectively

$C W D_{T}=33.7748 \exp (-0.2052 y r)$

and the equation

$C W D_{T}=44.8387 \exp (-0.1994 y r)$

Table 3 presents the resulting emission factors for changes in dead wood $\mathrm{C}$ pool for the forest-to-pasture conversion in $\mathrm{HG}$ and $\mathrm{LG}$ in tonnes of $\mathrm{CO}_{2}$ equivalent per hectare $\left(\mathrm{tCO}_{2} \mathrm{e}\right.$ ha ${ }^{-}$ $1)$. 


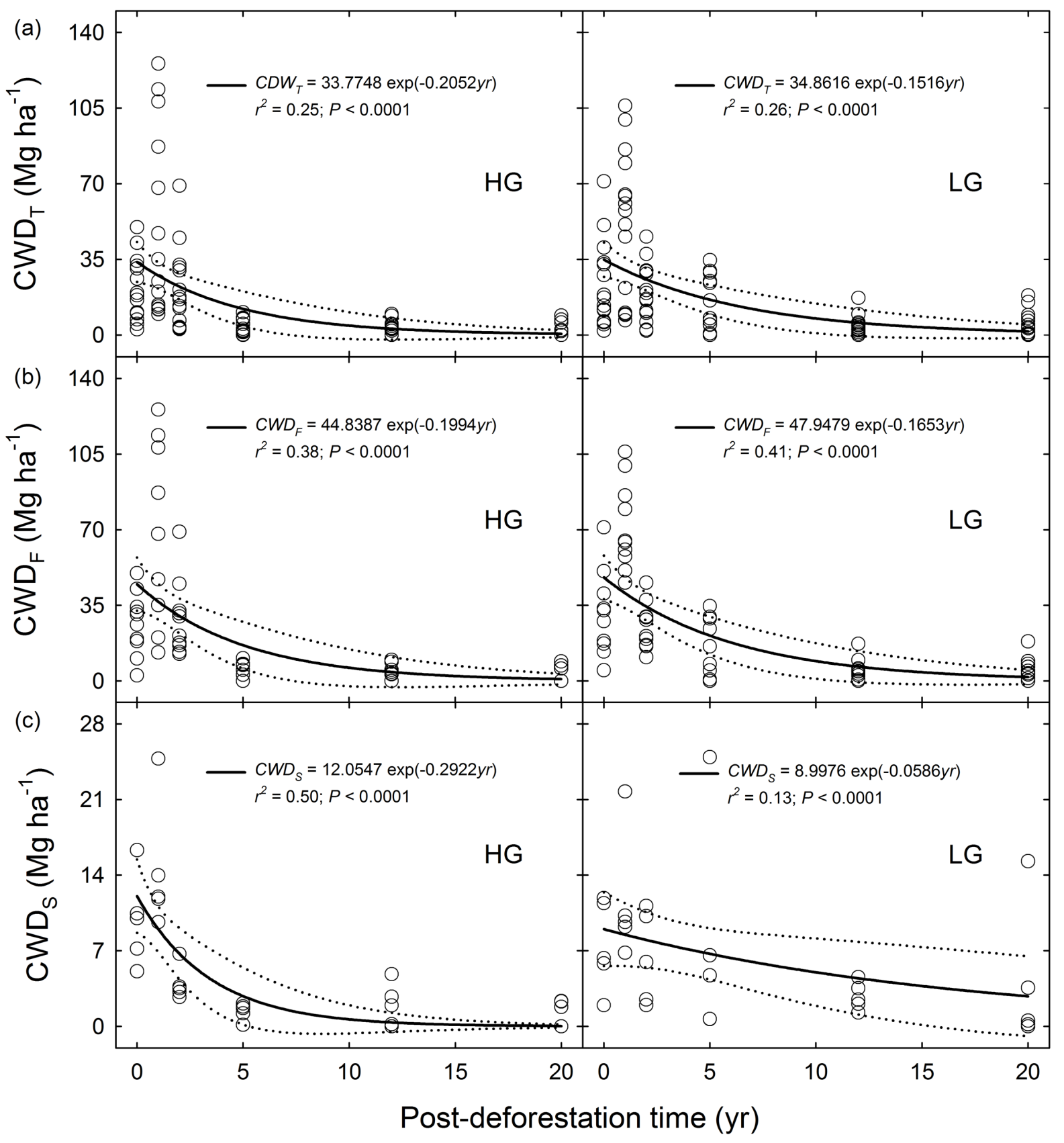

Fig. 4. Dead wood variation of (a) total $\left(\mathrm{CWD}_{\mathrm{T}}\right)$, (b) fallen $\left(\mathrm{CWD}_{\mathrm{F}}\right)$, and $(\mathrm{c})$ standing $\left(\mathrm{CWD}_{\mathrm{S}}\right)$ coarse woody debris during the forest-to-pasture conversion in the high-grazing intensity (HG) and the low-grazing intensity (LG) sub-regions of the Colombian Amazon. The dotted lines represent the $95 \%$ confidence interval. 
Table 3 Emission factors ( $\mathrm{CO}_{2} \mathrm{e} \mathrm{ha}^{-1}$ ) for changes in total (standing + fallen) dead wood $\mathrm{C}$ pool after 20 years of forest-to-pasture conversion in the high-grazing intensity (HG) and the low-grazing intensity (LG) sub-regions of the Colombian Amazon. Values in parenthesis represent the Confidence Interval (95\%).

\begin{tabular}{cclcl}
\hline \multirow{2}{*}{$\begin{array}{c}\text { Post-deforestation } \\
\text { time (yr) }\end{array}$} & \multicolumn{5}{l}{ Total CWD C pool $\left(\mathrm{t} \mathrm{CO}_{2} \mathrm{e} \mathrm{ha}^{-1}\right)$} \\
\hline 0 & 61.9 & $(16.8)$ & 63.9 & $(14.2)$ \\
1 & 50.4 & $(12.1)$ & 54.9 & $(10.3)$ \\
2 & 41.1 & $(12.3)$ & 47.2 & $(9.6)$ \\
3 & 33.5 & $(13.7)$ & 40.6 & $(10.4)$ \\
4 & 27.2 & $(14.2)$ & 34.9 & $(11.5)$ \\
5 & 22.2 & $(15.2)$ & 29.9 & $(13.1)$ \\
6 & 18.1 & $(15.1)$ & 25.7 & $(13.5)$ \\
7 & 14.7 & $(15.2)$ & 22.1 & $(13.3)$ \\
8 & 12.0 & $(13.5)$ & 19.0 & $(13.3)$ \\
9 & 9.8 & $(12.8)$ & 16.3 & $(13.4)$ \\
10 & 8.0 & $(11.7)$ & 14.0 & $(12.4)$ \\
11 & 6.5 & $(10.4)$ & 12.1 & $(12.0)$ \\
12 & 5.3 & $(9.2)$ & 10.4 & $(11.6)$ \\
13 & 4.3 & $(8.5)$ & 8.9 & $(10.9)$ \\
14 & 3.5 & $(7.3)$ & 7.7 & $(9.6)$ \\
15 & 2.9 & $(6.5)$ & 6.6 & $(9.0)$ \\
16 & 2.3 & $(5.9)$ & 5.7 & $(8.5)$ \\
17 & 1.9 & $(5.1)$ & 4.9 & $(7.6)$ \\
18 & 1.5 & $(4.0)$ & 4.2 & $(6.6)$ \\
19 & 1.3 & $(3.7)$ & 3.6 & $(6.1)$ \\
20 & 1.0 & $(2.8)$ & 3.1 & $(5.5)$ \\
\hline & & & &
\end{tabular}




\section{Discussion}

\subsection{CWD stocks in the forests of Colombian Amazon}

Total mean necromass (standing + fallen CWD) in the primary forests in both sub-regions of the Colombian Amazon presented here are in the middle of the range of those for lowland tropical forests presented by Baker et al. (2007). Estimates are slightly higher than the average values from the Peruvian Amazon (24.5 $\left.\pm 2.6 \mathrm{Mg} \mathrm{ha}^{-1}\right)$ and the whole Amazonian terra firme forests (31.6 $\left.\pm 2.7 \mathrm{Mg} \mathrm{ha}^{-1}\right)$ presented by Chao et al. (2009a). Reports on CWD stocks show that necromass tends to be higher in eastern and north-eastern Amazonia, reaching values of up to $86.6 \pm 13.4 \mathrm{Mg} \mathrm{ha}^{-1}$ at terra firme forests in Pará, Brazil (Rice et al., 2004), and decreases towards the west of the Amazon basin (Chao et al., 2009a). Rates of tree mortality and decomposition of dead wood have been proposed as the main factors controlling CWD stocks in Amazonian forests (Baker et al., 2007). It has been demonstrated that tree mortality in primary forests also increases from east to west across the Amazon basin (Phillips et al., 2004; Chao et al., 2009b), and that decomposition of CWD in tropical forests strongly depends on wood density and diameter (Harmon et al., 1995; Chambers et al., 2000). Baker et al. (2004) found that wood density tends to be $\sim 16 \%$ lower in northwest Amazonia compared to the central and eastern sectors, and Baker et al. (2007) showed that decomposition rates near Manaus, in the central Amazon, are lower compared to those in forests in southern Peru.

Most studies on CWD stocks, however, have been concentrated in the central and east (north and south) sectors of the Amazon (e.g. Chambers et al., 2000; Keller et al., 2004; Rice et al., 2004; Feldpausch et al., 2005; Palace et al., 2007) and just few have focused on the western region, mainly in the Peruvian Amazon (Baker et al., 2007; Chao et al., 2008; Araujo- 
Murakami et al., 2011; Banin et al., 2014). Only one study on necromass of standing dead trees was carried out in a terra firme forests in the Colombian Amazon, showing CWD stocks of $26.3 \pm 9.1 \mathrm{Mg} \mathrm{ha}^{-1}$ (Salarriaga et al., 1988). Therefore, reports on necromass in the HG and LG sub-regions presented here will help to reduce the uncertainty in CWD estimations in northwest Amazonia, particularly in the Colombian Amazon, and contribute with new information to strengthen regional patterns across the Amazon basin. Similarities in necromass of standing and fallen CWD between primary forests from both sub-regions of the Colombian Amazon indicate that CWD input rates and decomposition rates should also be similar between them.

One of the factors contributing to a high variability in CWD decomposition rates and necromass calculations is the error associated with wood density estimations (Chambers et al., 2000). The method of classifying dead wood into different decomposition classes has been widely used to estimate wood density (see Keller et al., 2004; Baker et al., 2007; Chao et al., 2008). However, the inherent subjectivity of the decay classification method increases the uncertainty associated with wood density estimates and makes it difficult to replicate the method and to compare among sites where classification has been done by different people (Larjavaara and Muller-Landau, 2010). In contrast, the total variability of the model we developed to predict CWD wood density based on objective penetration data using the dynamic penetrometer is mainly explained by this parameter $\left(r^{2}=0.65 ; P<0.0001\right)$ and can be replicated in sites where wood density is measured in the field by different people.

\subsection{Dead wood dynamics with land-use change under different management practices}


The results presented here show that land-cover change from forest to pasture strongly reduced the CWD stocks in both sub-regions of the Colombian Amazon. After 20 years of pasture establishment there was a net reduction of the total CWD necromass of $90 \%$ in $\mathrm{HG}$ and $75 \%$ in LG compared to the original values recorded in the primary forests in both subregions. An expected increase of $\sim 123 \%$ in total CWD necromass after cutting the forests followed by a reduction produced by fire events that reached similar values to those found in the forests were registered during the first two years after deforestation in both sub-regions. According to the farmers and land owners interviewed for this study, it is a common practice in $\mathrm{HG}$ and LG to burn the deforested areas in two to three fire events after cutting the forest to eliminate the greatest amount of dead wood produced after deforestation, as it has also been reported elsewhere in the Amazon. (Fearnside et al., 2001; Aragão and Shimabukuro, 2010). High mean annual precipitation and the very short dry season occurring in both sub-regions could explain the relatively low burning efficiency in HG and LG (Malhi et al., 2006; Armenteras-Pascual et al., 2011), in addition to chemical and physical properties of wood density or moisture content (Araujo et al., 1999). Assuming that farmers in both sub-regions perform two fire events after cutting the forest, burning efficiency in HG and LG was 29\% and $31 \%$, respectively. These results are similar to others reported for the Amazon, averaging 38\% of burning efficiency (Fearnside et al., 1993; Kauffman et al., 1995; Kauffman et al., 1998; Fearnside et al., 1999; Fearnside et al., 2001; IPCC, 2006).

Despite the similarities in necromass in the first two years of forest-to-pasture conversion, significant differences in CWD stocks between HG and LG arose during the second and fifth years of pasture establishment, when total necromass reduced $82 \%$ and $41 \%$, respectively, due to differences in management practices implemented in each sub-region. Whilst in HG the use of machinery to remove most of the residual CWD and remnant plant material not- 
consumed completely by fire is frequent, in LG farmers almost exclusively implement fire to remove the remnant wood produced after cutting the forest due to limitations to move heavy equipment to remote areas within the forest. In summary, the difference in management practices within a similar land-cover change category (i.e. forest to pasture) generates a pronounced difference in $\mathrm{C}$ emissions from dead wood $\mathrm{C}$ pool in the Colombian Amazon.

From the fifth year until the end of the 20 -year period of forest-to-pasture conversion, in the absence of any other management practice to eliminate the dead wood remaining from cutting the forest, the reduction of the CWD stocks should be explained by the decomposition processes occurring on the pasture surface in both sub-regions. In HG total necromass decreased $2.8 \mathrm{Mg} \mathrm{ha}^{-1}$ during the last 15 years of the pasture establishment, whereas in LG the reduction was $12.6 \mathrm{Mg} \mathrm{ha}^{-1}$ during the same period (see Table 2). These results would be plausible when considering that the non-use of machinery and the low grazing intensity in LG would favour the growth of secondary vegetation within the pasture matrix, which would accelerate decomposition rates of organic matter by increasing resources available for decomposer organisms during the first stages of secondary succession (Brown and Lugo, 1990). In fact, Navarrete et al. (unpublished) found that C3- and C4-derived C increases along the same chronosequence of 20 years of forest-to-pasture conversion due to the growth of secondary vegetation within the pasture matrix in LG.

Mean wood density values presented in this study tended to increase from the forest stage to the end of the 20-year chronosequence. Although it is expected that dead wood density declines as decomposition progresses with time (Harmon et al., 2000), the highest values of dead wood density registered at the old pastures in HG and LG would reflect the fact that 
living trees with high wood density have more probability to resist decomposition and, therefore, to persist at the oldest stages of the chronosequence (Melin et al., 2009)

Studies evaluating the variation of CWD stocks with land-cover change are scarce. For example, Eaton and Lawrence (2006) reported an increase of 38\% in the CWD stocks when the forest was converted to agricultural land in a dry tropical region in the south of Mexico after slash-and-burn practice was used. Saldarriaga et al. (1988) evaluated dead biomass along a chronosequence of forest succession from young forests with a CWD stocks of $1.1 \mathrm{Mg} \mathrm{ha}^{-1}$ to mature forests (see above). Some other studies on CWD necromass have compared undisturbed with degraded or secondary forests in the tropics. For instance, Berenguer et al., (2014) found that the dead wood C pool in the eastern Brazilian Amazon forests appears to be resistant to the effects of logging and fire, and shows similar CWD stocks between undisturbed and degraded forests. Some other studies have compared undisturbed forests with forests under conventional logging and the so-called 'reduced impact logging' where harvesting practices have been improved in order to reduce the impact on the residual forest stand in the Brazilian Amazon. Keller et al. (2004), for example, reported that average fallen necromass at Cauaxi was 55.2 $\pm 4.7,74.7 \pm 0.6$ and $107.8 \pm 10.5 \mathrm{Mg} \mathrm{ha}^{-1}$ for undisturbed, reduced impact logging and conventional logging sites, respectively, and was $50.7 \pm 1.1$ and 76.2 $\pm 10.2 \mathrm{Mg} \mathrm{ha}^{-1}$ for undisturbed and reduced impact logging at Tapajós. Palace et al. (2007) reported values of fallen necromass of $44.9 \pm 0.2$ and $67.0 \pm 0.2 \mathrm{Mg} \mathrm{ha}^{-1}$ and standing necromass of $5.3 \pm 1.0$ and $8.8 \pm 2.3 \mathrm{Mg} \mathrm{ha}^{-1}$, for undisturbed and reduced impact logging sites in Pará, respectively.

\subsection{Improving dead wood carbon pool emission factors (Tier 3)}


Dead wood is one of the $\mathrm{C}$ pools recommended by IPCC to be assessed as part of the emission factors conforming the Forest Reference Emission Level (FREL) that countries implementing REDD+ activities should submit to the UNFCCC (FAO, 2014), and also to be included in the national greenhouse gas inventories within the AFOLU sector (IPCC, 2006). However, under an IPCC Tier 1 approach it should be considered that $100 \%$ of $\mathrm{C}$ contained in the dead wood C pool is emitted immediately after deforestation, conservatively assuming that necromass has a value of zero in a post-deforestation land category such as pastures (IPCC, 2003; IPCC, 2006). In fact, all countries that submitted their FREL to the UNFCCC by 2014 conservatively excluded the dead wood C pool from their final report (Conafor, 2014; GYC, 2014; MADS, 2014; MAE, 2014; MMA, 2014; MNRE, 2014). Countries participating in REDD+ also have the option to establish Tier 3 field-based inventories to capture the long-term legacy effects of land-cover change on dead wood $\mathrm{C}$ pool, in order to improve the accuracy of emission factors on CWD stocks and variation associated with landuse change activities (IPCC, 2006). However, country- or region-specific information including the dead wood $\mathrm{C}$ pool is limited, resulting in highly uncertain emission factors within the REDD+ national programmes (Angelsen et al., 2012).

The results presented in this study on C stocks in dead wood and their decrease after 20 years of the forest-to-pasture conversion in two sub-regions with different management practices in terms of grazing intensity in the Colombian Amazon, are the first data set and equations developed under the IPCC Tier 3 approach using region-specific information (see Fig. 4 and Table 3). Considering that countries have the option to submit their initial FRELs including a limited number of C pools, and subsequently improve them by incorporating highquality data, improved methodologies and additional pools (UNFCCC, 2012), the information presented here has the potential to improve the emission factors to be included in the next 
Colombian FREL by adding Tier 3 information on dead wood $\mathrm{C}$ pool and its net change due to the conversion from forest to pasture in the Colombian Amazon.

\section{Conclusions}

Our study suggests that conversion from forest to pasture during 20 years in the Colombian Amazon leads to a pronounced reduction in the dead wood $\mathrm{C}$ pool, although management practices implemented in the high- and low-grazing intensity sub-regions also greatly influences CWD stocks in the following different ways:

- Volume, wood density and necromass of standing and fallen CWD in primary forests of the Colombian Amazon are similar between HG and LG, and are within the range of CWD stocks in other Amazon forests reported elsewhere.

- During the first two years of forest-to-pasture conversion, management practices resulted in an increase of $124 \%$ in HG and $123 \%$ in LG in CWD stocks when the forest was cut, and a subsequent decrease to similar levels to those found in the original forest when fire was applied in two events with low levels of burning efficiency.

- Implementation of machinery to remove dead wood still remaining after the use of fire (i.e. between the second and fifth year of pasture establishment) generated a notably decrease of $82 \%$ of CWD stocks in $\mathrm{HG}$, compared to a reduction of $41 \%$ in $\mathrm{LG}$.

- During the last 15 years of pasture establishment the rate of CWD loss was greater in LG, presumably as a consequence of an increase in decomposition rates related to the secondary succession. Management practices in HG include the elimination of secondary vegetation growing in the pasture matrix, retarding the re-establishment of decomposer community. 
- The implementation of low-grazing management practices after pasture establishment, including a reduction in the use of machinery, the implementation of a silvopastoral system, or the reduction of the cattle density per hectare to values equal or below to the pasture carrying capacity, could contribute to reduce $\mathrm{CO}_{2}$ emissions following deforestation by better preserving the $\mathrm{C}$ stored in the dead wood after 20 years of forest-to-pasture conversion compared to pastures under high-grazing practices

\section{Acknowledgements}

This study was funded by AXA Research Fund (2012-Doc-University-of-ExeterNAVARRETE-D). We thank Walter Navarrete, Arcesio Pijachi, Nancy Encinales, Germán Alvarado, Manuel Encinales and David Alvarado for their valuable help with field sampling, accommodation and transportation. We also thank Dr Gabriel Colorado, Pablo Palacios and Dr Juan Suárez Salazar for their help in providing space, equipment and materials in laboratories at Universidad Nacional de Colombia and Universidad de la Amazonia. Finally, we thank the Instituto de Hidrología, Meteorología y Estudios Ambientales de Colombia (Ideam) for supplying the data to calculate mean annual precipitation and temperature, and for supporting the development of the model to estimate wood density.

\section{References}

Alarcón, M., Tabares, E., 2007. Economía y usos de la biodiversidad: actividad pecuaria. In: Diversidad biológica y cultural del sur de la Amazonia colombiana - Diagnóstico (eds. Ruiz, S.L., Sánchez, E., Tabares, E., Prieto, A., Arias, J.C., Gómez, R., Castellanos. D., 
García, P., Rodríguez, L.), Corpoamazonia, Instituto Humboldt, Instituto Sinchi, UAESPNN, pp. 314-316.

Angelsen, A., McNeill, D., 2012. The evolution of REDD+. In: Analysing REDD+:

Challenges and Choices (eds. Angelsen, A., Brockhaus, M., Sunderlin, W.D., Verchot, L.V.), CIFOR, Bogor, Indonesia, pp. 31-50.

Aragão, L.E.O.C., Shimabukuro, Y.E., 2010. The Incidence of Fire in Amazonian Forests with Implications for REDD. Science. 328, 1275-1278.

Araújo, T.M., Carvalho, J.A. Jr, Higuchi, N., Brasil, A.C.P. Jr, Mesquita, A.L.A., 1999. A tropical rainforest clearing experiment by biomass burning in the state of Pará, Brazil. Atmos. Environ. 33, 1991-1998.

Araujo-Murakami, A., Parada, A.G., Terán J.J., Baker, T.R., Feldpausch, T.R., Phillips, O.L., Brienen, R.J.W., 2011. Necromasa de los bosques de Madre de Dios, Perú; una comparación entre bosques de tierra firme y de bajíos. Rev. Peru. Biol. 18, 113-118.

Armenteras-Pascuala, D., Retana-Alumbreros, J., Molowny-Horas, R., Roman-Cuesta, R.M., Gonzalez-Alonso, F., Morales-Rivas, M., 2011. Characterising fire spatial pattern interactions with climate and vegetation in Colombia. Agr. Forest. Meteorol. 151, 279289.

Asner, G.P., Townsend, A.R., Bustamante, M.M.C., Nardoto, G.B., Olander, L.P., 2004. Pasture degradation in the central Amazon: linking changes in carbon and nutrient cycling with remote sensing. Glob. Change. Biol. 10, 844-862.

Baker, T.R., Honorio Coronado, E.N., Phillips, O.L., Martin, J., van der Heijden, G.M.F., García, M., Silva Espejo, J., 2007. Low stocks of coarse woody debris in a southwest Amazonian forest. Oecologia. 152, 495-504.

Baker, T.R., Phillips, O.L., Malhi, Y., Almeida, S., Arroyo, L., Di Fiore, A., Erwin, T., Killeen, T.J., Laurance, S.G., Laurance,W.F., Lewis, S.L., Lloyd, J., Monteagudo, A., 
Neill, D.A., Patiño, S., Pitman, N.C.A., Silva, J.N.M., Vásquez Martínez, R., 2004.

Variation in wood density determines spatial patterns in Amazonian forest biomass. Glob. Change. Biol. 10, 545-562.

Banin, L., Lewis, S.L., Lopez-Gonzalez, G., Baker, T.R., Quesada, C.A., Chao, K-.J., Burslem, D.F.R.P., Nilus, R., Salim, K.A., Keeling, H.C., Tan, S., Davies, S.J., Monteagudo Mendoza, A., Vásquez, R., Lloyd, J., Neill, D.A., Pitman, N, Phillips, O.L., 2014. Tropical forest wood production: a cross-continental comparison. J. Ecol. 102, $1025-1037$.

Berenguer, E., Ferreira, J., Gardner, T.A., Aragão, L.E.O.C., De Camargo, P.B., Cerri, C.E., Durigan, M., De Oliveira, R.C., Vieira, I.C.G., Barlow, J., 2014. A large-scale field assessment of carbon stocks in human-modified tropical forests. Glob. Change. Biol. 20, $3713-3726$.

Bowman, M.S., Soares-Filho, B.S., Merry, F.D., Nepstad, D.C., Rodrigues, H., Almeida, O.T., 2012. Persistence of cattle ranching in the Brazilian Amazon: A spatial analysis of the rationale for beef production. Land Use Policy. 29, 558-568.

Brown, S., Lugo, A.E., 1990. Effects of forest clearing and succession on the carbon and nitrogen content of soils in Puerto Rico and US Virgin Islands. Plant Soil. 124, 53-64.

Cabrera, E., Vargas, D.M., Galindo, G., García, M.C., Ordóñez, M.F., Vergara, L.K., Pacheco, A.M., Rubiano, J.C., Giraldo, P., 2011. Memoria técnica de la cuantificación de la deforestación histórica nacional escalas gruesa y fina. Instituto de Hidrología, Meteorología, y Estudios Ambientales (IDEAM), Bogota, Colombia, pp. 106.

Chambers, J.Q., Higuchi, N., Schimel, J.P., Ferreira, L.V., Melack, J.M., 2000.

Decomposition and carbon cycling of dead trees in tropical forests of the central Amazon. Oecologia. 122, 380-388. 
Chao, K.-J., Phillips, O.L., Baker, T.R., 2008. Wood density stocks of coarse woody debris in a northwestern Amazonian landscape, Can. J. For. Res. 38, 795-825.

Chao, K.-J., Phillips, O.L., Baker, T.R., Peacock, J., Lopez-Gonzalez, G., Vasques Martinez, R., Monteagudo, A., Torres-Lezama, A., 2009a. After trees die: quantities and determinants of necromass across Amazonia. Biogeosciences. 6, 1615-1626.

Chao, K.-J., Phillips, O.L., Monteagudo, A., Torres-Lezama, A., Vasques Martinez, R., 2009b. How do trees die? Mode of death in northern Amazonia. J. Veg. Sci. 20, 260-268.

Clark, D.B., Clark, D.A., Brown, S., Oberbauer, S.F., Veldkamp, E., 2002. Stocks and flow of coarse woody debris across a tropical rain forest nutrient and topography gradient. Forest Ecol. Manag. 164, 237-2448.

Conafor, 2014. Propuesta del nivel de referencia de las emisiones forestales de México. Comisión Nacional Forestal, pp. 51.

Creed, I.F., Webster, K.L., Morrison, D.L., 2004. A comparison of techniques for measuring density and concentrations of carbon and nitrogen in coarse woody debris at different stages of decay. Can. J. For. Res. 34, 744-753.

Desjardins, T., Barros, E., Sarrazin, M., Girardin, C., Mariotti, A., 2004. Effects of forest conversion to pasture on soil carbon content and dynamics in Brazilian Amazonia. Agr. Ecosyst. Environ. 103, 365-373.

Dias-Filho, M., Davidson, E.A., Carvalho, C.J.R., 2000. Linking biogeochemical cycles to cattle pasture management and sustainability in Amazon Basin. In Biogeochemistry of the Amazon Basin, McClain, M., Victoria, R.L., Eds., Oxford University: New York, pp. 84105.

Don, A., Schumacher, J., Freibauer, A., 2011. Impact of tropical land-use change on soil organic carbon stocks - a meta-analysis. Glob. Change. Biol. 17, 1658-1670. 
Eaton, J.M., Lawrence, D., 2006. Woody debris stocks and fluxes during succession in a dry tropical forest. Forest Ecol. Manag. 232, 46-55.

Eggleton, P., Bignell, D.E., Sands, W.A., Waite, B., Wood, T.G. Lawton, J.H., 1995. The species richness of termites (Isoptera) under differing levels of forest disturbance in the Mbalmayo Forest Reserve, southern Cameroon. J. Trop. Ecol. 11, 85-98.

FAO, 2014. Emerging approaches to Forest Reference Emission Levels and/or Forest Reference Levels for REDD+. UN-REDD Programme, FAO, UNDP, UNEP, Rome, pp. 54.

Fearnside, P.M., Barbosa, R., 1998. Soil carbon changes from conversion of forest to pasture in Brazilian Amazonia. Forest Ecol. Manag. 108, 147-166.

Fearnside, P.M., Graça, P.M.L.A., Rodrigues, F.J.A., 2001. Burning of Amazonian rainforests: burning efficiency and charcoal formation in forest cleared for cattle pasture near Manaus, Brazil. Forest Ecol. Manag. 146, 115-128.

Fearnside, P.M., Leal Filho, N., Fernandes, F.M., 1993. Rainforest Burning and the Global Carbon Budget: Biomass, Combustion Efficiency, and Charcoal Formation in the Brazilian Amazon. J. Geophys. Res. 98, 16733-16743.

Fearnsidea, P.M., Graça, P.M.L.A., Leal, N., Rodrigues, F.J.A., Robinsonb, J.M., 1999. Tropical forest burning in Brazilian Amazonia: measurement of biomass loading, burning efficiency and charcoal formation at Altamira, Pará. Forest Ecol. Manag. 123, 65-79.

Fedegan, 2013. Análisis del inventario ganadero colombiano para el año $2013-$ Corpontamiento y variables explicativas. Federación Colombiana de Ganaderos, Bogota, pp. 37.

Feldpausch, T.R., Rondon, M.A., Fernandes, E.C.M., Riha, S.J., Wandelli, E., 2004. Carbon and nutrient accumulation in secondary forests regenerating on pastures in central Amazonia. Ecol. Appl. 14, S164-S176. 
Feldpausch, T.R., Jirka, S., Passos, C.A.M., Jasper, F., Riha, S.J., 2005. When big trees fall: Damage and carbon export by reduced impact logging in southern Amazonia. Forest Ecol. Manag. 219, 199-215.

Fisher, M.J., Braz, S.P., dos Santos, R.S.M., Urquiaga, S., Alves, B.J.R., Boddey, R.M., 2007. Another dimension to grazing systems: Soil carbon. Trop. Grasslands. 41, 65-83.

GFC, 2014. The Reference Level for Guyana's REDD+ Program. Guyana Forestry Commission, pp. 57.

Gibbs, J.P., Hunter, M.L, Melvin, S.M., 1993. Snag Availability and Communities of Cavity Nesting Birds in Tropical versus Temperate Forests. Biotropica. 25, 236-241.

González, J., Cubillos, A., Arias, M., Zapata, B., 2014. Resultados de la simulación de la deforestación para el ajuste del nivel de referencia del área subnacional A8. Instituto de Hidrología, Meteorología y Estudios Ambientales (IDEAM) - Ministerio de Ambiente y Desarrollo Sostenible, Bogota, Colombia, pp. 42.

Grove, S.J., 2002. Saproxylic insect ecology and the sustainable management of forests. Annu. Rev. Ecol. Syst. 33, 1-23.

Harmon, M.E., Franklin, J.F., Swanson, F.J., Sollins, P., Gregory, S.V., Lattin, J.D., Anderson, N.H., Cline, S.P., Aumen, N.G., Sedell, J.R., Lienkaemper, G.W., Cromack, K., Cummins, K.W., 1986. Ecology of coarse woody debris in temperate ecosystems. Adv. Ecol. Res. 15, 133-302.

Harmon, M.E., Whigham, D.F., Sexton, J., Olmsted, I., 1995. Decomposition and mass of wood detritus in the dry tropical forests of northeastern Yucatan Peninsula, Mexico. Biotropica. 27, 305-316.

Harmon, M.E., Krankina, O.N., and Sexton, J., 2000. Decomposition vectors: a new approach to estimating woody detritus decomposition dynamics. Can. J. Forest Res., 30, 76-84. 
Harris, N.L., Brown, S., Hagen, S.C., Saatchi, S.S., Petrova, S., Salas, W., Hansen, M.C., Potapov, P.V., Lotsch, A., 2012. Baseline Map of Carbon Emissions from Deforestation in Tropical Regions. Science, 336, 1573-1576.

IDEAM, 2014. Mapa de Cambio de Bosque periodo 2010-2012 para la región A8-Amazonia, Regiones Alta y Baja, versión 5.0. con resolución espacial de 30 metros de pixel en formato raster temático. Instituto de Hidrología, Meteorología, y Estudios Ambientales (IDEAM), Bogota, Colombia.

IPCC, 2003. Good practice guidance for land use, land-use change and forestry (eds Penman, J., Gytarsky, M., Hiraishi, T., Krug, T., Kruger, D., Pipatti, R., Buendia, L., Miwa, K., Ngara, T., Tanabe, K., Wagner, F.), Published by the Institute for Global Environmental Strategies (IGES), Hayama, Japan, pp. 632.

IPCC, 2006. 2006 IPCC guidelines for national greenhouse gas inventories. Voulme 4: Agriculture, Forestry and Other Land Use (eds Eggleston HS, Buendia L, Miwa K, Ngara T and Tanabe K), Published by the Institute for Global Environmental Strategies (IGES), Hayama, Japan, pp. 679.

Jiménez, J.J., Lal, R., 2006. Mechanisms of C Sequestration in Soils of Latin America. Crit. Rev. Plant. Sci. 25, 337-365.

Kauffman, J.B., Cummings, D.L., Ward, D.E., 1998. Fire in the Brazilian Amazon 2. Biomass, nutrient pools and losses in cattle pastures. Oecologia. 113, 415-427.

Kauffman, J.B., Cummings, D.L., Ward, D.E., Babbitt, R., 1995. Fire in the Brazilian Amazon: 1. Biomass, nutrient pools, and losses in slashed primary forests. Oecologia. 104, $397-408$.

Keller, M., Palace, M., Asner, G.P., Pereira, R., Silva, J.N.M., 2004. Coarse woody debris in undisturbed and logged forests in the Eastern Brazilian Amazon. Glob. Change. Biol. 10, 784-95. 
Larjavaara, M., Muller-Landau, H.C., 2010. Comparison of decay classification, knife test, and two penetrometers for estimating wood density of coarse woody debris. Can. J. For. Res. 40, 2313-2321.

Luyssaert, S., Jammet, M., Stoy, P.C., Estel, S., Pongratz, J., Ceschia, E., Churkina, G., Don, A., Erb, K.H., Ferlicoq, M., Gielen, B., Grünwald, T., Houghton, R.A., Klumpp, K., Knohl, A., Kolb, T., Kuemmerle, T., Laurila, T., Lohila, A., Loustau, D., McGrath, M.J., Meyfroidt, P., Moors, E.J., Naudts, K., Novick, K., Otto, J., Pilegaard, K., Pio, C.A., Rambal, S., Rebmann, C., Ryder, J., Suyker, A.E., Varlagin, A., Wattenbach, M., Dolman, A.J., 2014. Land management and land-cover change have impacts of similar magnitude on surface temperature. Nature Clim. Change. 4, 389-393.

MADS, 2014. Proposed Forest Reference Emission Level for deforestation in the Colombian Amazon Biome for results-based payments for REDD+ under the UNFCCC. Ministry of Environment and Sustainable Development of Colombia, Bogota, pp. 40.

MAE, 2014. Ecuador's Forest Reference Emission Level for Deforestation. Ministry of the Environment of Ecuador, Quito, pp. 46.

Malhi, Y., Wood, D., Baker, T.R., Wright, J., Phillips, O.L., , Cochrane, T, Meir, P., Chave, J., Almeida, S., Arroyo, L., Higuchi, N., Killeen, T.J. Laurance, S.G., Laurance, W.F, Lewis, S.L., Monteagudo, A., Neill, D.A., Nuñez Vargas, P., Pitman, M.C.A, Quesada, C.A., Salomão, R., Silva, J.N.M., Torres Lezama, A., Terborgh, J., Vásquez Martíne, R., Vinceti, B., 2006. The regional variation of aboveground live biomass in old-growth Amazonian forests. Glob. Change. Biol. 12, 1107-1138.

Marin-Spiotta, E., Silver, W.L., Swanston, C.W., Ostertag, R., 2009. Soil organic matter dynamics during 80 years of reforestation of tropical pastures. Glob. Change. Biol. 15, $1584-1597$. 
Melin, Y., Petersson, H., and Nordfjell, T., 2009. Decomposition of stump and root systems of Norway spruce in Sweden. A modelling approach. Forest Ecol. Manag., 257, 14451451.

MMA, 2014. Brazil's submission of a Forest Reference Emission Level (FREL) for reducing emissions from deforestation in the Amazonia biome for REDD+ results-based payments under the UNFCCC. Ministry of the Environment of Brazil, Brasilia, pp. 130.

MNRE, 2014. Malaysia's Submission on Reference Levels for REDD+ Results Based Payments under UNFCCC. Ministry of Natural Resources and Environment, Malaysia, pp. 18.

Mosquera, O., Buurman, P., Ramirez, B.L., Amezquita, M.C., 2012. Carbon stocks and dynamics under improved tropical pasture and silvopastoral systems in Colombian Amazonia. Geoderma. 190, 81-86.

Murty, D., Kirschbaum, M.U.F., McMurtrie, R.E., McGilvray, H., 2002. Does conversion of forest to agricultural land change soil carbon and nitrogen? A review of the literature. Glob. Change. Biol. 8, 105-123.

Nepstad, D.C., Stickler, C.M., Soares-Filho, B., Merry, F., 2008. Interactions among Amazon land use, forests and climate: prospects for a near-term forest tipping point. Phil. Trans. R. Soc. B. $363,1737-1746$.

Pacheco, P., Putzel, L., Obidzinski, K., Schoneveld, G., 2012. REDD+ and the global economy Competing forces and policy options. In: Analysing REDD+: Challenges and Choices (eds. Angelsen, A., Brockhaus, M., Sunderlin, W.D., Verchot, L.V.), CIFOR, Bogor, Indonesia, pp. 55-66.

Palace, M., Keller, M., Asner, G.P., Silva, J.N.M., Passos, C., 2007. Necromass in undisturbed and logged forests in the Brazilian Amazon. Forest Ecol. Manag. 238, 309318. 
Palace, M., Keller, M., Hurtt, G., Frolking, S., 2012. A review of above ground necromass in tropical forests. In: Tropical Forests (eds Sudarshana, P., Nageswara-Rao, M., Soneji, J.R.), ISBN: 978-953-51-0255-7, InTech, pp 215-252.

Palace, M., Keller, M., Silva, H., 2008. Necromass production: studies in undisturbed and logged amazon forests. Ecol. Appl. 18, 873-884.

Pedlar, J.H., Pearce, J.L., Venier, L.A., McKenney, D.W., 2002. Coarse woody debris in relation to disturbance and forest type in boreal Canada. Forest Ecol. Manag. 158, 189194.

Pfeifer, M., Lefebvre, V., Turner, E., Cusack, J., Khoo, M.S., Chey, V.K., Peni, M., Ewers, R.M., 2015. Deadwood biomass: an underestimated carbon stock in degraded tropical forests? Environ. Res. Lett. 10, 1-11.

Phillips, J.F., Duque, A.J., Scott, C., Peña, M.A., Franco, C.A., Galindo, G., Cabrera, E., Álvarez, E., Cárdenas, D., 2014. Aportes técnicos del Sistema de Monitoreo de Bosques y Carbono a la propuesta de preparación de Colombia para REDD+: datos de actividad y factores de emisión. Memoria técnica. Instituto de Hidrología, Meteorología, y Estudios Ambientales (IDEAM), Bogota, Colombia, pp. 45.

Phillips, O.L., Baker, T.R., Arroyo, L., Higuchi, N., Killeen, T.J., Laurance, W.F., Lewis, S.L., Lloyd, J., Malhi, Y., Monteagudo, A., Neill, D.A., Núñez Vargas, P., Silva, J.N.M., Terborgh, J., Vásquez Martínez, R., Alexiades, M., Almeida, S., Brown, S., Chave, J., Comiskey, J.A., Czimczik, C.I., Di Fiore, A., Erwin, T., Kuebler, C., Laurance, S.G., Nascimento, H.E.M., Olivier, J., Palacios, W., Patiño, S., Pitman, N.C.A., Quesada, C.A., Saldias, M., Torres Lezama, A., Vinceti, B., 2004. Pattern and process in Amazon tree turnover, 1976-2001. Phil. Trans. R. Soc. B. 359, 381-407. 
Rice, A.H., Hammond Pyle, E., Saleska, S.R., Hutyra, L., Palace, M., Keller, M., De Camargo, P.B., Portilho, K., Marques, D.F., Wofsy, S.C., 2004. Carbon balance and vegetation dynamics in an old-growth Amazonian forest. Ecol. Appl. 14, S55-S71.

Saldarriaga, J.G., West, D.C., Tharp, M.L., Uhl, C., 1988. Long-Term Chronosequence of Forest Succession in the Upper Rio Negro of Colombia and Venezuela. J. Ecol. 76, 938958.

Taylor, J.R., 1997. An introduction to error analysis: the study of uncertainties in physical measurements. Second edition. University Science Books, Sausalito, California, pp. 349.

Uhl, C., Clark, K., Dezzeo, N., Maquirino, P., 1988. Vegetation dynamics in Amazonian treefall gaps. Ecology. 69, 751-763.

UNFCCC, 2012. Decision 12/CP.17. In: Report of the Conference of the Parties on its seventeenth session, held in Durban from 28 November to 11 December 2011 (United Nations Framework Convention on Climate Change), pp. 16-19.

van Engelen, V.W.P., Dijkshoorn, J.A., 2013. Global and national soils and terrain digital databases (SOTER). Procedure Manual, version 2.0, ISRIC, World Soil Information, Wageningen, pp. 198.

Verchot, L.V., Anitha, K., Romijn, E., Herold, M., Hergoualc'h, K., 2012. Emissions factors: Converting land use change to $\mathrm{CO} 2$ estimates. In: Analysing REDD+: Challenges and Choices (eds Angelsen A, Brockhaus M, Sunderlin WD, Verchot LV), CIFOR, Bogor, Indonesia, pp. 261-278.

Yepes, A. P., Navarrete, D. A., Duque, A. J., Phillips, J. F., Cabrera, K. R., Álvarez, E., García, M. C., Ordoñez, M.F., 2011. Protocolo para la estimación nacional y subnacional de biomasa - carbono en Colombia. Instituto de Hidrología, Meteorología, y Estudios Ambientales (IDEAM), Bogota, Colombia, pp. 162.

Zar, J., 1999. Biostatistical analysis. Fourth edition. Prentice-Hall. USA, pp. 718. 
